\title{
Implementation of Regulatory Impact Assessment (RIA) to Salt National Industry in Indonesia
}

\author{
Arif Haendra* \\ Management and Business Study Program, IPB University \\ PO box 16151, Jl Pajajaran Raya No 63, Bogor, Indonesia \\ M. Syamsul Maarif \\ Management and Business Study Program, IPB University \\ PO box 16151, Jl Pajajaran Raya No 63, Bogor, Indonesia \\ Joko Affandi \\ Management and Business Study Program, IPB University \\ PO box 16151, Jl Pajajaran Raya No 63, Bogor, Indonesia \\ Anggraini Sukmawati \\ Management and Business Study Program, IPB University \\ PO box 16151, Jl Pajajaran Raya No 63, Bogor, Indonesia
}

\begin{abstract}
Salt is one of strategic commodities in Indonesia. The incompetence in fulfilling salt national needs makes salt national consumption depends on imported salt. Public policy based on needs to solve the problem that happened in community, the contra productive regulation makes Law No. 7 Year 2016 about protection and empowerment of fishermen, fish cultivators, and salt farmers becomes ineffective. This research aims to analyze the government policy related to salt national industry with methodology used Regulatory Impact Assessment (RIA) by involving the experts and practitioners also policy makers of Indonesia salt industry. The result of analysis and public consultation refers to analysis of costs and benefit by repairing the policy that has been issued.To get the best alternative can be done by arranging the strategic and real actions that can erase or minimalize from costs or existence problems. Besides that on Regulation of the Minister of Industry of Indonesia Number:88/MIND/PER/10/2014 SNI various food salt that is $\mathrm{NaCl}$ minimum $94 \%$, this research tried to propose $\mathrm{NaCl}$ content to be changed become minimum $94 \%$ and maximum $97 \%$ to increase absorption of people's salt, increasing the level of people's health by mineral fortification in the salt and technical barrier to imported products.
\end{abstract}

Keywords: Competitiveness, Salt, Strategy, Regulatory Impact Assessment (RIA)

DOI: $10.7176 / \mathrm{EJBM} / 13-7-07$

Publication date: April $30^{\text {th }} 2021$

\section{Introduction}

Indonesia is a maritime country with the shoreline length 108,000 km (Communication Bureau of the Coordinating Ministry for Maritime and Investment 2018), Indonesia has big potential as the biggest salt producer in the world, but that is not balanced with the work of salt national production. Salt in Indonesia is included on strategic commodity and politic commodity (Salim and Munadi2016). In the past years there is an imbalance in demands and offers of salt commodity in the country that made dependability of salt national consumption on imports.

The problem happened in salt national industry can be seen from the production salt that is the low of production volume and tend not to increase, depend on weather and other social environment problems. On the other side the needs of salt national since 2015 until 2020 continue to increase. The increasing of salt demand from years to years is not balanced with increasing of salt production. To fulfill the national needs, it effects the high dependability on imports (Table 1).

Table 1 Production, import, and salt needs in Indonesia 2015-2019 (ton)

\begin{tabular}{|c|c|c|c|c|c|}
\hline Year & Salt National Production & Import & Amount & Salt National Needs & Difference \\
\hline 2015 & $2,485,111$ & $1,864,049$ & $4,349,160$ & $3,227,279$ & $1,121,881$ \\
\hline 2016 & 168,054 & $2,143,743$ & $2,311,797$ & $3,532,887$ & $-1,221,090$ \\
\hline 2017 & 1111,395 & $2,552,283$ & $3,663,678$ & $3,862,925$ & $-199,247$ \\
\hline 2018 & $2,719,256$ & $2,718,659$ & $5,437,915$ & $3,960,945$ & $1,476,970$ \\
\hline 2019 & $2,327,078$ & $2,724,772$ & $5,051,850$ & $4,197,622$ & 854,228 \\
\hline
\end{tabular}

Source: Data box of Economic and Business of Indonesia Data Centre

The purpose of government do the salt import is to fulfilment of salt downstream industry that demand the 
salt quality specifically, stable supply, and price stabilization to increase the growth of national economy by multiplier effect on salt downstream industry (Report of Garam Company, 2020). But the reality the imported salt now caused the salt stock in Indonesia increase and cannot be sold. The low of quantity and quality the country's products is not only one factor that influence the big quota of Indonesia salt import. It needs the government action as regulator to balance the various stakeholders that is industry, salt farmers/producers in this country, salt processor and consumers.

Local salt or people's farmer salt is not yet able to produce the $\mathrm{NaCl}$ content with percentage above $95 \%$ with level of low impurities that needs by industry. The standard that applied in SNI the raw industry CAP and food various industry cause the people's farmers difficult to fulfill those criteria. The local salt rejected by industry because the low quality if it compared with imported salt. On the other side, the price of imported salt is very low, about USD 23-30 per ton CIF arrived in Indonesia harbor (Industry Ministry, 2020). This condition caused oversupply of local salt and the fall of salt price.

There are some regulations that must get attention related to import management that is: Regulation of Indonesia Minister of Trade Number 63 Year 2019 is implementation Article 6 Government Regulation Number 9 Year 2017 about the control management of Fish Import Commodity and Salt Commodity as a Raw Materials and Industrial Auxiliary Materials, also to support the increasing of national competitiveness and gives certainty work in import of salt commodity. Besides that Regulation of East Java Governor Number 78 Year 2011 managed the import control management about import permission that issued by central government while permission of unloading will give after getting recommendation from Industry and Trade Service East Java Province. The control management regulations above should be the instruments to manage time, total, and unloading location of imported salt so it will not disturb the price of people's salt importantly in harvest time. The imported salt is not only have purpose to fulfill the user of industry needs but also protect the salt farmers, giving certainty work in salt downstream that continuous also support the increasing of national competitiveness and giving certainty work in salt production.

The research related to salt policy in Indonesia has been done by some researcher. Suhendiet al. (2020) studied the regulation policy of imported salt in Indonesia is not yet effective so it needs strategy and some reparation action so the policy can be effective optimally. The strategy that can be done are by repairing the imported salt management by strengthening data collection system, supervision of local salt and law enforcement. Dharmayantiet al (2013) said that sustainable self-sufficiency can be reached on consumed salt, while salt industry has not been reached. The increasing of quantity and quality of people's salt, and conversion salt simultaneously is needed to apply in Indonesia. Then more Baihaki (2013) stated that Indonesia is not yet able to reduce the sum of imported salt. No seriousness of government can be seen from the minimum coordination between central government and regional government in accompanying the salt farmers. The production of salt domestic and the price of imported salt have negative relation with import volume (Jamil et al., 2017).Al Bram (2016) by the descriptive research stated that law policy product is not yet fulfill the economy worker of salt national. Because of that the study about salt national industry policy need to support the strategy of salt industry growth and its products for the future and strengthening competitiveness of industry.

Public policy is aware activities, directed, and measured that has been done by government that involve the important side in a certain field that refers to certain purpose (Ramdhani\&Ramdhani, 2017). The purpose from a public policy is can be reach the public welfare by the regulation made by the government. Because of the effectiveness of policy implementation is important to be studied. The policy effectiveness that has been issued can be shown by seeing the effect from that policy to the public welfare especially accordance with that policy purpose.

In the moment to reach the target of salt self-sufficiency, the government planned to reduce the imported salt gradually. In the context of imported salt policy the purpose is how the salt needs in the country can be fulfilled and on the other side the salt farmer also protected. To make the purpose real in making the public welfare including the Fishermen, Fish Cultivators, and Salt Farmers, the country issued the Law Number 7 Year 2016 to give the Protection and Fishermen Empowerment, Fish Cultivators, and Salt Farmers in planned, directed, and sustainable.

Based on the background above, the analysis of government policy related to salt national industry be focussed in this research. There is aim for this research is to analyse Indonesia government policy related to salt national industry now. To create salt self-sufficiency in Indonesia, it needs the right regulation to increase the salt competitiveness by seeing from production side, market and Indonesia economy to improve the domestic salt farmer welfare and increase country income.

\section{Research Method}

This research was done in Garam Company that is state-owned enterprise (BUMN) in producing and marketing the salt. The time measurement and data collection was done on August 2020-February 2021. Design of this research used causative research (cause and effect) which this research method used Regulatory Impact 
Assessment (RIA). Data used in this research is primary data there are interview and the result of forum group discussion, also secondary data there is literature study of regulation that related to the needs of salt national.

In this research Regulatory Impact Assessment (RIA) used to measure systematically the negative and positive effect of regulation that is being proposed or currently running. RIA can be used as policy evaluation tool, besides that can be used as determinant of taking decision. RIA systematically and consistence study the effect that come up by government action and communicate the policy information to the decision makers. Besides that, RIA also has function to make sure systematically the chosen choice of policy which is more effective and efficient and also communicate the information to decision makers. The steps that done in doing RIA analysis are:

Regulatory Impact Assessment (RIA) used to measure sitematically the negative and positive effect of regulation that is being proposed or currently running. RIA is one of method that used to analyze the effect of enforcement of regulation and tool that fundamentally to hel the government in measuring the effect of regulation (Susanto et al, 2016). Generally there are the steps of RIA based on OECD (2008): (1) Formulation of the problem, (2) Aim Identification, (3) Arranging problem alternative solution, (4) Analysis the cost and benefit and (5) Public consultation and choose the best alternative also (6) Strategy of implementation.

\section{Result and Discussions}

RIA analysis on this study was done on the Regulation of Indonesia Industry Ministry Number: 88/MIND/PER/10/2014 about the Change of the Regulation of Indonesia Industry Ministry Number: 134/MIND/PER/10/2009 about the Road Map Cluster Developing of Salt Industry, but the regulation that has been issued is cannot be separated from regulation above as explained on Figure 1.

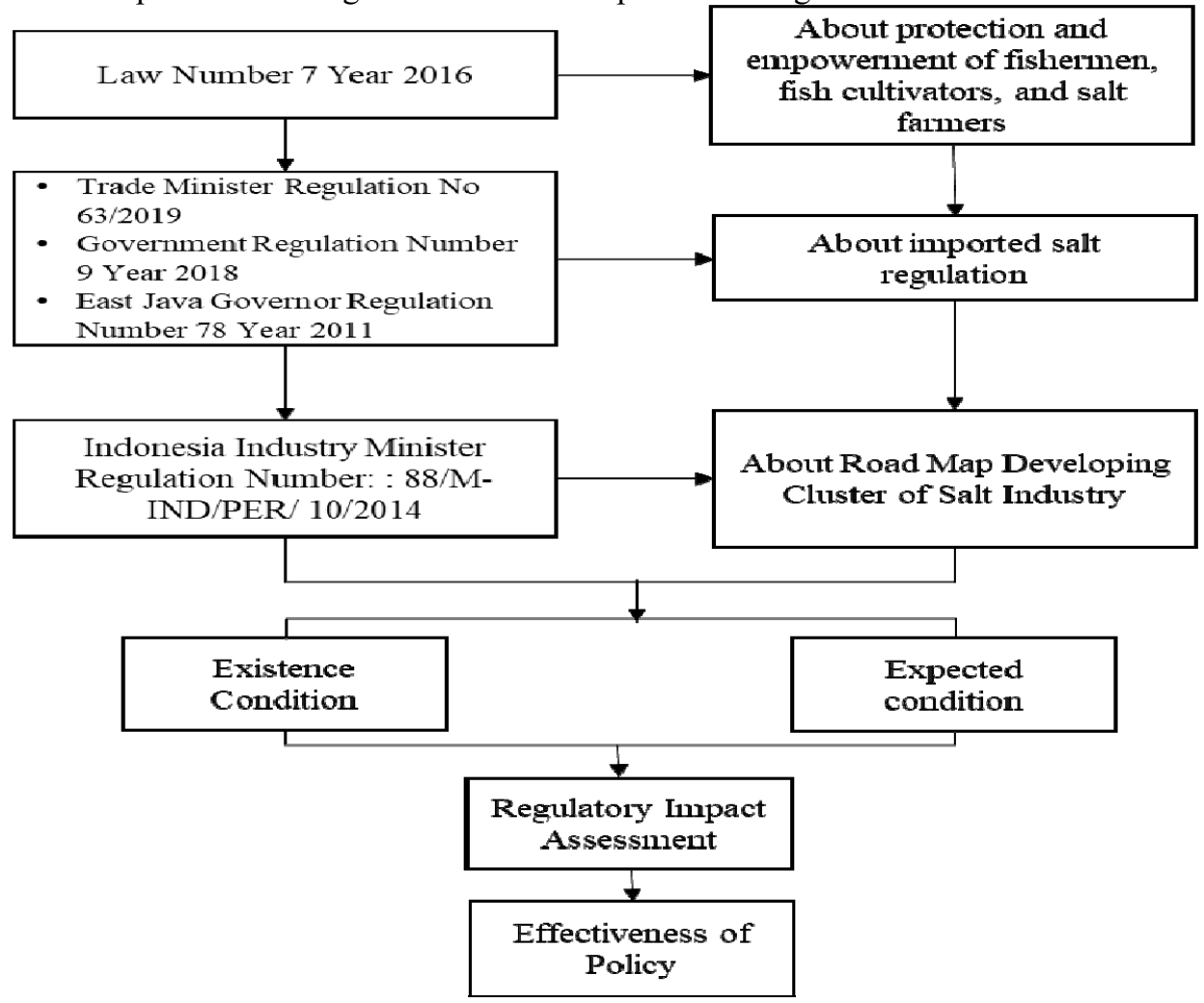

Figure 1 Flow of research analysis

\subsection{Policy Analysis}

The policy related to the salt is analyzed based four policies that related each other there are Law Number 7 Year 2016, Regulation of Indonesia Trade Minister Number 63 Year 2019 is implementation of Article 6 Government Regulation Number 9 Year 2018, Regulation of East Java Governor Number 78 Year 201, and Regulation of Indonesia Industry Ministry Number: 88/M-IND/PER/ 10/2014.

The government policy about empowerment and development of salt farmers. To manifest the country purpose to make people welfare, including fishermen, fish cultivators, and salt farmers, the country issued The Law Number 7 Year 2016, to held Protection and Empowerment of Fishermen, Fish Cultivators, and Salt Farmers in planned, directed, and sustainable. Protection and Empowerment of Fishermen, Fish Cultivators, and Salt Farmers have purpose for: 
a) providing facilities that needed in developing work;

b) giving certainty of work that sustainable;

c) increasing the skill and capacity of of Fishermen, Fish Cultivators, and Salt Farmers; strengthening the agency in managing the fish source and sea source also doing independent, productive, progressive, modern and sustainable work; and developing principle of environmental sustainability;

d) growing up system and agency of financing that serve work interest;

e) protecting from risk of natural disaster, climate change, also polution; and

f) giving guarantee of security and safety also legal assistance.

3.1.1 Policy of imported salt

In the moment to reach the salt self-sufficiency, the government plan to decrease the imported salt gradually. In the context of policy imported salt the purpose is how the need of salt needs in the country can be fulfilled and the other side the salt farmers also protected.The Regulation of Indonesia Trade Minister Number 63 Year 2019 is implementation of Article 6 Government Regulation Number 9 Year 2018 about Managing Control of Fish Import Commodity and Salt Commodity as Raw Material and Industry Auxiliary Material, also to support the increasing of national competitiveness and give the certainty of work in imported salt commodity. Salt that can be imported is a salt to fulfill the raw material and industry auxiliary material.

Salt can be imported by the company that owned master number attempted (NIB) that valid as producer importer identification number (API-P) that has got Salt Imported Approval from Ministry. The Salt Imported Approval has data and information minimum about:

a. The amount and kind of salt

b. Tariff post/HS and detail of thing

c. Loading port

d. Country of Origin

e. Destination Port

f. Validity period of Salt Imported Approval

Besides that The Regulation of East Java Governor Number 78 Year 2011 about Controlling of Salt and Empowerment of Salt Working thought that:

a. Salt is strategic commodity as one of raw industry material and additional food each year always has increasing order, that cannot be fulfill by salt production inside the country because less to fulfill the quality standard and its amount, so the companies prefer to choose salt imported to fulfill the purposed needs.

b. East Java as one of region that produce the salt in Indonesia, has enough large of salt farmers.

c. Based on the consideration above to prevent the conflict of interest between the salt imported company and salt farmers as the domestic salt suppliers, so it needs the problem management of controlling imported salt and empowerment of people's work of salt in Governor Regulation.

3.1.2 Road Map of Cluster developing of salt industry

According to Regulation of Indonesia Trade Minister Number: 88/M-IND/PER/ 10/2014 about the Change of Indonesia Industry Ministry Number: 134/M-IND/PER/10/2009 about Road Map of Cluster developing of salt industry stated that cluster developing of salt industry has been changed as in Figure 2

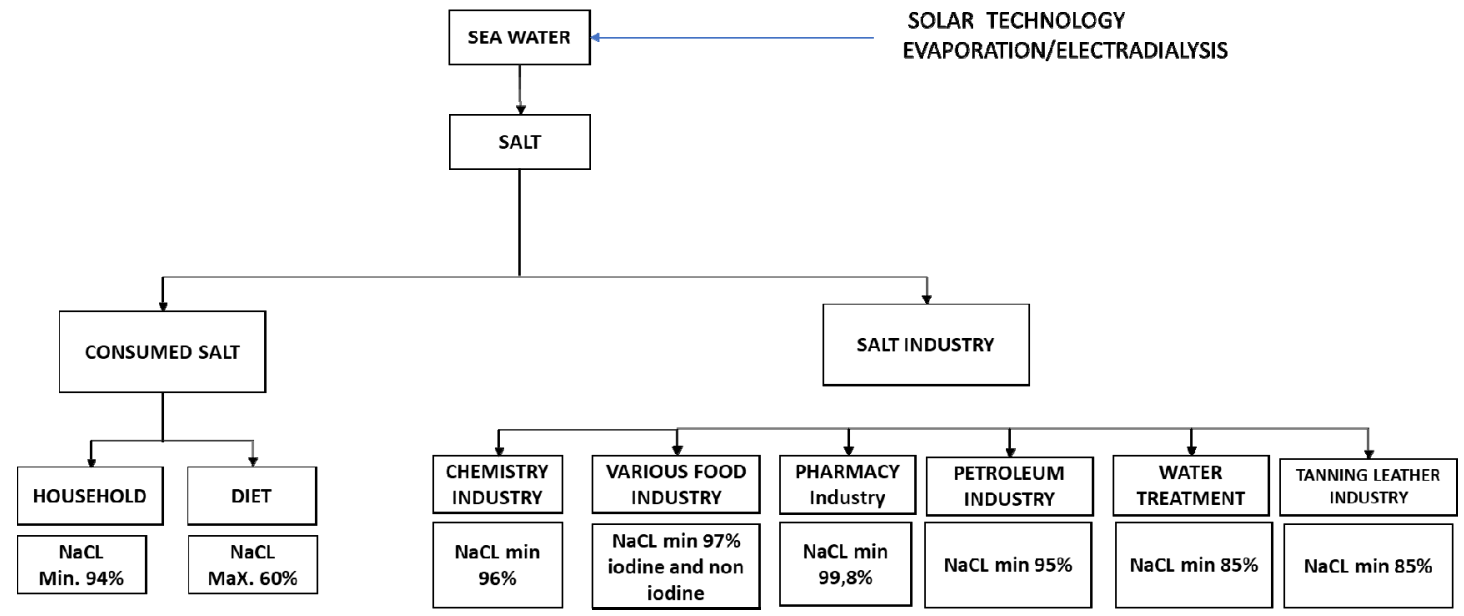

Source: Industry Ministry 2014 (Regulation of Indonesia Industry Minister Number: 88/M-IND/PER/ 10/2014)

Figure 2 Road Map of Cluster developing of salt industry 


\subsection{Regulatory Impact Assessment(RIA) to Salt Policy in Indonesia}

\subsubsection{Formulation of the Problem}

According the policy study and also information that has been got from many sources there are some problem related to salt so it issued the regulation Law Number 7 Year 2016 about protection and empowerment of fishermen, fish cultivators, and salt farmers. The spirit from the Law Number 7 Year 2016 for the salt farmers, article 18 number 6 is the role of government in providing infrastructure of salt working, so it can increase the work smoothness in making salt in the form of sump pool of raw water, production, salting land, warehouse and drains. From 5 aspects the government already been concentrate in providing the facility of warehouse by program National Salt Warehouse (GGN). And about the effort of increasing quality by land integration, providing raw reservoir, drains and production has not yet built optimally.

Based on road map of cluster developing salt industry to be more competitiveness, Regulation of Indonesia Industry Minister Number: 88/M-IND/PER/10/2014 about the change of Regulation of Indonesia Industry Minister Number: 134/M-IND/PER/10/2009 about road map of cluster developing salt industry manage that cluster developing industry divided into 2 (two) there are consumed salt and salt industry with different regulation based on SNI. This regulation cause salt with local raw material cannot compete with imported raw salt that has quality that fulfill that SNI that cause additional cost.

\subsubsection{Aim of Identification}

The aim of the regulation issued is to push the national salt industry to be more competitiveness, increasing the quality and quantity of production supported by imported salt commodity controlling effectively and also giving protection and empowerment to the salt farmers. The coaching by the government directed to fulfill the industry needs that has growth of demand $6 \%-7 \%$ per year, access to capital and infrastructure also market certainty.

The cluster of salt used also refers to give clearly separation between salt as raw material or auxiliary material for industry activity and given incentive to push multiplier effect of next economy activity, while cluster of consumed salt is used as final product and be specialized only for fulfilled from local salt.

\subsubsection{Arranging alternative problem solution}

Alternative solution to solve the problem are first the policy that has been issued. This solution is done if this policy has been effective accordance with the expected purpose. Second, improving the regulation that has been issued. This solution is done if the policy has not yet been effective but can still be repaired. The improvement is minor which some of purpose that has been reached and improvement is done to fulfil the expected goal. Third, cancelling the policy that has been issued. This solution is done if this policy is not effective and not be able to reach the goal set.

\subsubsection{Cost Analysis and Benefit}

To identify a cost and benefit in policy related to competitiveness of salt that sustainable, doing identification for everyone that get effect and who get the benefit because of that chosen policy. While main stakeholder that involved or get the benefit from this policy are:

a) Government

b) Garam Company

c) End-user

d) Processor

e) Farmer or Cooperative

f) Fund Agency

In doing analysis related to cost and benefit, so doing the comparison between condition which has not yet the policy, nowadays condition, and expected condition. This comparison is aimed to show the effectiveness from policy that has been used. If nowadays condition is better than before the condition and accordance with the expectation so that policy can be said effective and can be used. But if nowadays condition worse so the policy is not effective and needs the reconsideration and stopped.

Before the policy problems occurred, are:

a) Condition of salt farmers is very cause for concern, because only rely on salt produce to fulfill their daily needs. In addition with the condition of uncertain weather cause the pond sank. The regulation at that moment, less giving guarantee of legal assistance for salt farmers.

b) Imported salt industry especially industry of various food, must be proceed by processor so it can be categorized food grade salt. In that processing in the factory, imported salt mixed with consumed salt which processor usually has product of consumed salt that sold directly to the market as iodine consumed salt. Detection and sanction to this thing become a part of regulation about cluster of salt and done consistently.

c) Before the policy occurred there is still monopolistic activity of imported salt and considered as the source of waste and extend the bureaucratic chain of salt imported, and private industry players get fair treatment in accessing the sources of raw salt industry. 
Table 2 Analysis of Cost and Benefit

\begin{tabular}{|c|c|c|c|}
\hline \multirow{2}{*}{ Stakeholder } & \multirow{2}{*}{ Expectation/goal } & \multicolumn{2}{|c|}{ Existing Condition } \\
\hline & & Positive effect (benefit) & Negative effect (cost) \\
\hline Government & $\begin{array}{l}\text { Salt } \\
\text { sufficiency can be } \\
\text { achieved }\end{array}$ & $\begin{array}{l}\text { Commitment to push the } \\
\text { national salt industry from the } \\
\text { beginning until finish which } \\
\text { integrated as technology, } \\
\text { production, and access to } \\
\text { increase the quality of local } \\
\text { salt and can fulfill the needs of } \\
\text { consumed salt or industry salt. }\end{array}$ & $\begin{array}{l}\text { The difficult of absorbing people's salt: } \\
\text { - The price is not competitive; the high } \\
\text { of cost production and the long market } \\
\text { chain so it causes the high of local salt } \\
\text { price. } \\
\text { - The stock is not continuously; the } \\
\text { production of people's salt is still } \\
\text { depends on sunshine, so the } \\
\text { production process become only } \\
\text { effective on } 3 \text { months in a year. } \\
\text { - The low quality, people's salt has NaCl } \\
\text { contained } 93.1 \%-97.3 \% \text {. On the other } \\
\text { side SNI minimum NaCl of food } \\
\text { various salt } 97 \% \text { im accordance with } \\
\text { CODEX FAO, pharmacy salt must } \\
\text { contain NaCl } 99 \% \text {. }\end{array}$ \\
\hline $\begin{array}{l}\text { Garam } \\
\text { Company }\end{array}$ & $\begin{array}{l}\text { Competitiveness } \\
\text { and Sustainable } \\
\text { National Salt }\end{array}$ & $\begin{array}{l}\text { - Potency of salt lands } \\
\text { production in Indonesia 550- } \\
615 \text { thousand tons per year } \\
\text {-The company does not do } \\
\text { monopolistic production so } \\
\text { it can use the available } \\
\text { source fully to increase the } \\
\text { quality and quantity of } \\
\text { production and cooperate } \\
\text { with salt farmers. }\end{array}$ & $\begin{array}{l}\text { The result of salt production is not sold } \\
\text { as expectation because the low price of } \\
\text { imported. } \\
\text { If Garam Company compete with the } \\
\text { price of imported salt so it will more } \\
\text { push the price of salt farmer until low } \\
\text { price, below on farmers' production. }\end{array}$ \\
\hline Industry & $\begin{array}{lr}\text { Getting local } & \text { salt } \\
\text { industry } & \text { that } \\
\text { qualified } & \text { and } \\
\text { affordable } & \end{array}$ & $\begin{array}{l}\text { No difficulty in getting salt } \\
\text { industry accordance with } \\
\text { quality and quantity with } \\
\text { competitive price. }\end{array}$ & $\begin{array}{l}\text { There are additional cost because of } \\
\text { logistic cost, unsustainable supply. }\end{array}$ \\
\hline $\begin{array}{l}\text { Processor } \\
\text { /importir }\end{array}$ & 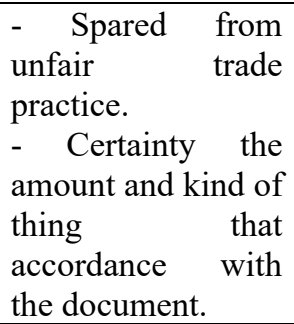 & $\begin{array}{l}\text { - Can get raw materials } \\
\text { anytime not depend on the } \\
\text { season } \\
\text { - The cost production is very } \\
\text { efficient, the higher benefit. }\end{array}$ & $\begin{array}{l}\text { - The relationship with the salt } \\
\text { farmers do not trust each other, the } \\
\text { safety of working is not guarantee. } \\
\text { Salt industry mixed and sold as } \\
\text { consumed salt. }\end{array}$ \\
\hline $\begin{array}{l}\text { Farmers or } \\
\text { Cooperative }\end{array}$ & $\begin{array}{l}\text { - Increasing of salt } \\
\text { production. } \\
\text { - High price of salt } \\
\text { and increasing } \\
\text { the quality. } \\
\text { - Salt production } \\
\text { absorb with } \\
\text { market industry. }\end{array}$ & $\begin{array}{l}\text { Increasing the welfare of } 100 \\
\text { thousand farmers directly and } \\
200 \text { thousands that work in } \\
\text { salt sector (transportation, } \\
\text { farm workers, traders and } \\
\text { collection, equipment rental) }\end{array}$ & $\begin{array}{l}\text { Inability in balancing the demands of } \\
\text { national salt caused unstable price that } \\
\text { cause social turmoil. }\end{array}$ \\
\hline Fund Agency & $\begin{array}{l}\text { good production } \\
\text { and commerce of } \\
\text { salt so the credit } \\
\text { fund smooth }\end{array}$ & $\begin{array}{l}\text { Giving the capital help } \\
\text { especially to the salt farmers } \\
\text { and involving in salt farmers' } \\
\text { welfare }\end{array}$ & $\begin{array}{l}\text { Probability of bad credit because of the } \\
\text { farmer price production is bigger that } \\
\text { sold price. }\end{array}$ \\
\hline
\end{tabular}

Analysis of cost and benefit as explained on the Table 2 is done as qualitative based on the situation on the field now. According to analysis cost and benefit can be concluded that the policy is not yet effective to push the development of quality and quantity production of salt to national salt self-sufficiency. The regulation that gives benefit rather than before the regulation, but the cost (negative effect) that cause still there and probable to do 
improvement to minimize the negative effect. To be effective the cost so the problem must be solved and need the strategic and new innovation by industry players and government.

3.2.5 Public Consultation and choose the best alternative

The regulation of Indonesia Industry Minister Number: 88/M-IND/PER/10/2014 is focussed on road map of cluster development salt industry. But it refers to the produce analysis cost benefit, this regulation is much related with increasing effort productivity salt farmers to increase the quality of salt production so it can be competitiveness. Besides that on Regulation of Indonesia Industry Minister Number: 88/M-IND/PER/10/2014 said that for salt SNI of various food industry stated $\mathrm{NaCl}$ minimum $97 \%$, while based on the result of cost and benefit, this research tries to propose $\mathrm{NaCl}$ content to be changed minimum $94 \%$ and maximum $97 \%$ as technical barrier.

To make implementation of Indonesia Industry Minister Number: 88/M-IND/PER/10/2014 more effective to push the national salt industry production, it needs consideration to change the cluster salt from consumed salt-salt industry, to be food salt non-food. This thing to difference the salt used as raw industry material that used directly and include in cluster non-salt food. Salt food is salt that process in the factory to change the raw material that can be eaten, both as consumed salt and as salt raw food various industry material.

To be more independent and competitiveness the steps that taken by the government is by issuing the policy that much related with self-sufficiency economy. Boonkam (2011) explained that self-sufficiency economy probable the country to do modernization, not anti-globalization but also prepare the self to dispel negative effect from economic transaction. Based on the result of analysis it is known that to make the policy effective is doing strategic and action as improvement and policy implementation.

It can be concluded that alternative strategy that can be developed on the policy related salt commodity in general, are:

On Farm Strategy, can be done by some technical steps as follow:

a. Land Intensification

The level of salt land productivity in Indonesia is still very low. The farmer land productivity is about 6080 tons/ha/year, while Garam Company land is about 80-100 tons/ha/year. This thing still far below the average the salt land production in Indian and Australia that reach 300-350 tons/ha/year. This thing as effect of salt production that done still use the traditional system, without mechanization for harvest so it is very depended on the available and ability the worker on the top of harvest. To support the productivity improvement of farmer land so technology implementation of harvest mechanization needs to be applied. The sea water processing system as salt raw material must be standardized so it can get the old water that accordance with the need with the quality minimum $240 \mathrm{Be}$ in crystallization. This ideal condition if it can be reached, it can increase the salt production capacity until reach 150 tons/ha/year so with the land now, national production can be reached twofold or reach 5 million tons/year

b. Land Extensification

The need of salt production is increasing each year, salt production can be more depended on the land nowadays. The salt land is much in the middle of the city, so it is less effective and more of them switch the function. The government has planned to open the salt lands in Nusa Tenggara Timur (NTT) province to manage as modern and intregated. Besides increasing the production in existance salt central, Indonesia needs it.

c. Utilization

To make increasing of salt farmers' capacity, so the alternative be focused to improve the capacity of human resources and agency to increase the production of The Community of People's Salt Working (KUGAR) that involved skill, ability, and knowledge. Besides the application of KUGAR it need PUGAR (KKP 2020). PUGAR is empowerment program that focused on chance improvement of work and welfare for salt farmers by principle bottom-up, means salt farmer will involve the planned program, the held and do monitoring and evaluation accordance with determined mechanism.

Off Farm Strategy. This thing can be done by some technical actions as follow:

a. Salt industry

Increasing added value of national salt by processing the salt raw material from farmers to be food grade. The factory that processing the people's salt need to be built in salt production central and manage by salt cooperative, and the production result is bought by various food industry. The demand of salt industry until now reach 700,000 tons per year and still increase along with development of national foods and beverages industry(KKP, Industry, Trade, BPS 2020)

b. Consumed Salt

Consumed salt if for household, fish salting and other food used, should be fulfill by local salt cannot be mixed with imported salt. The amount of $\mathrm{NaCl}$ content that needed for this kind of salt does not need to be high as salt industry but it is completed with other minerals fortification beside the iodine that has been implemented during this time. The needs of this consumed salt is $2.5 \mathrm{~kg}-3 \mathrm{~kg} / \mathrm{caita} / \mathrm{year}$, so the Indonesia 
national needs reach 800,000 tons/year (Salim Z and Munadi 2016 and BPS 2020).

c. Downstream

Salt as raw material is the main component of Chlor Alkali Plant (CAP) industry that is Sodium Hydroxide $(\mathrm{NaOH})$ factory. Now, all the needs of CAP industry raw materials are from import. Besides that, salt is the main raw material for Soda Ash (Na2CO3) which now Indonesia is net importer 100\% soda ash with the total 1,000,000 tons/year. To produce 1,000,000 tons of soda ash needs about 1,400,000 ton/year. As the effort of absorption national salt, it can be planned to substitute the needs of soda ash by building soda ash factories inside the country by using local raw materials.

Marketing Strategy. This can be done by some technical actions as follow:

a. Raw salt

To prevent the impact in the market between raw salt Garam Company and people's salt, so it needs market separation. Raw salt produced by Garam Company must be processed to be processed salt. While people's salt, if by the policy of salt as basic and important goods (bapokting) should be manage by special agency or government as Garam Company as off taker so it sold as raw consumed salt to the processing factories (processor) or the needy industry.

b. Processed

Raw salt can be processed to be consumed salt, salt for industry of various food or other products that salt based, there are gargle salt for tooth and mouth health, fruit washing salt, salt spa for tourism industry or skincare or other instant seasoning products.

Innovations this processed products must keep doing remember additional value if the salt has been processed to be other lifestyle products be bigger. Marketing/Sale of salt can use the distribution way with community based to be more efficient and be able to develop economy of community. Salt as staple and be sure needed by each households, can be sold in daily activity of community outside the market. As example, cooperation between Garam Company and Muslimat NU.

\section{Conclusion}

The result of the research using RIA method explained that Regulation of Indonesia Industry Minister Number: 88/M-IND/PER/ 10/2014 that has been focussed to the roadmap cluster developing salt industry, has a chance to be improved. Although there is regulation that gives benefit than before the regulation, but the cost (negative effeet) that caused still there and probable to do improvements to minimize the negative effect. Because of that, the researcher make proposal related to Regulation of Indonesia Industry Minister Number: 88/M-IND/PER/ $10 / 2014$ and its derivatives that is salt SNI for various food industry with $\mathrm{NaCl}$ content minimum $97 \%$ changed to be minimum $94 \%$ and for maximum $97 \%$ as technical barrier.

Besides that, to improve the attractiveness of the development of the upstream salting industry, it needs reclusterization from division of consumed salt cluster-salt industry to be food salt cluster-non food salt. This change will push the investment of new salting land.

Next, the strategy can be developed after the government do the policy improvement related to salt commodity by on farm strategy and marketing strategy.

\section{References}

Al Bram, H.D. (2016). Implikasi Liberalisasi Perdagangan Terhadap Sektor Garam Nasional (Studi Kasus Kebijakan Garam Impor di Jawa Timur . Litigasi, Vol. 17(1), 2016, 3133-3166.

Baihaki, L. (2013). Ekonomi-Politik Kebijakan Impor Garam Indonesia Periode 2007-2012. Jurnal Ilmu Sosial dan Ilmu Politik. 17, 1

Biro Komunikasi Kementerian Koordinator Bidang Kemaritiman dan Investasi. (2018). Menko Maritim Luncurkan Data Rujukan Wilayah Kelautan Indonesia. Kementerian Koordinator Bidang Kemaritiman Dan Investasi.

Boonkam, S. (2012). The sufficiency economy: a Thai solution to economic sustainability. http://www.triplepundit.com/2011/05/sufficiency-economy-thai-solution-economic-sustainability/ [28 February 2021]

[BPS] Badan Pusat Statistik. 2020. https://www.bps.go.id/

Dharmayanti, S., Suharno., Rifin, A. (2014). Analisis Ketersediaan Garam Menuju Pencapaian Swasembada Garam Nasional Yang Berkelanjutan (Suatu Pendekatatan Model Dinamik). Jurnal Sosek KP. 8, 1.

Hasan, M. (2020). Swasembada Garam Nasional Dipersimpangan Jalan. Himpunan Masyarakat Petambak Garam Jawa Timur.

Jamil, A.S., Tinaprilla, N. \& Suharno. (2017). Faktor-Faktor Yang Memengaruhi Permintaan dan Efektivitas Kebijakan Impor Garam Indonesia. Buletin Ilmiah Litbang Perdagangan, Vol.11 No.1, Juli 2017.

[KKP] Kementerian Kelautan dan Perikanan. (2020). Siaran Pers: Atasi Masalah Garam Rakyat Di Sektor Hulu Melalui Pugar. (https://kkp.go.id/djprl/artikel/16496-kkp-atasi-masalah-garam-rakyat-di-sektor-hulu- 
melalui-pugar/ (11Maret 2021]

[OECD] Organisation for Economic Co-operation and Development. (2008). Building anInstitutional Framework for RegulatoryImpact Analysis, Guidance for PolicyMaker. OECD. Paris.

[Permen] Peraturan Menteri Perindustrian Republik Indonesia Nomor 88/M IND/PER/10/2014 tentang perubahan atas peraturan Menteri Perindustrian nomor 134/MIND/PER/10/2009 tentang petapanduan (roadmap) pengembangan klaster industri garam.

[PP]Peraturan Pemerintah Republik Indonesia Nomor 9 Tahun 2018 tentang Tata Cara Pengendalian Impor Komoditas Perikanan dan Komoditas Pergaraman Sebagai Bahan Baku dan Bahan Penolong Industri. 2018 b.

PT Garam (persero). (2020). Laporan Tahunan.

Salim, Z dan Munadi, E. (2016). Info Komoditi Garam. Badan Pengkajian Dan Pengembangan Perdagangan Al Mawardi Prima.

Suhendi., Abdullah, A., Shalihati, F. (2020). The effectiveness of the salt policy in Indonesia. Jurnal Manajemen \& Agribisnis, Vol. 17 No. 3, November 2020

Susanto, D.A., Suprapto \& Hadiyanto, J. (2016). Regulatory Impact Analisys Terhadap Pemberlakuan Standar Nasional Indonesia Biskuit Secara Wajib. Jurnal Standardisasi. 18, 3, 217 - 228.

[UU] Undang-Undang Nomor 7 Tahun 2016 tentang Perlindungan dan Pemberdayaan Nelayan, Pembudidaya Ikan dan Petambak Garam. 2016.

http://www.p2ptm.kemkes.go.id/artikel-penyakit/butuh-berapa-banyak-garam-tubuh-kita-per-hari/[10Maret 2021] 